\title{
SHORT-TERM AND LONG-TERM IMPACTS OF ECO-DRIVING ON DYNAMICS OF DRIVING BEHAVIOUR AND OPERATING PARAMETERS
}

\author{
Tatjana SAVKOVIĆ ${ }^{1}$, Milica MILIČIĆ ${ }^{2}$, Ilija TANACKOV ${ }^{3}$, Pavle PITKA ${ }^{*}$, Dejan KOLEŠKA ${ }^{5}$ \\ 1,2,3,4 Dept of Traffic Engineering, Faculty of Technical Sciences, University of Novi Sad, Novi Sad, Serbia \\ ${ }^{5}$ Scania BH d.o.o., Sarajevo, Bosnia and Herzegovina
}

Received 5 April 2018; revised 13 February 2019; accepted 6 April 2019

\begin{abstract}
This paper shows the impact of eco-driving training course on driving behaviour of 7 drivers, analysing two internal parameters: Scania Driver Support (SDS) parameter and Fuel Consumption (FC). Data were collected using Scania Fleet Management System (Scania FMS) over a period of one-year $(1+2+4+6$ months during the 2015 and 2016). Data for these two parameters of all drivers were recorded daily over a one-year period and calculated in average values on a monthly basis. A one-year cycle of average monthly ambient temperatures of wider geographical region was adopted as the most important external parameter of impact on eco-driving benefits. Longitudinal observation period is divided into: one month initial period of establishing the parameter values before the training (one month), short-term with ecodriving (two months), short-term without eco-driving (four months) and long-term (six months). Significantly higher values of SDS parameter $(p<0.05)$ and significant reduction of FC $(p=0.0310<0.05)$ were established with a higher average ambient temperature over a short-term period. A partial increase of SDS parameter value $(p<0.10)$ was established over a long-term period but the level of FC reversed to the values as before the training $(p=0.7554>0.05)$. The results indicate the potential of eco-driving training that manifests significantly positive effects only in good driving conditions. With bad weather conditions that correlate with bad driving conditions, the effects of eco-driving training are supressed with increased requirements for safer driving. Primary conclusion of the paper is that the eco-driving training principles have an apparent positive effect on reduction of $\mathrm{FC}$ and $\mathrm{CO}_{2}$ emission but are at the same time sensitive to environmental driving conditions.
\end{abstract}

Keywords: eco-driving, ambient temperature, fuel consumption, $\mathrm{CO}_{2}$ emission, driving conditions.

\section{Notations}

Variables:

$\Delta_{F C}$ - potential monthly reduction of fuel consumption;

$\Delta_{\mathrm{CO}_{2}}$ - potential monthly reduction of $\mathrm{CO}_{2}$ emissions;

$\Delta_{E B}$ - potential monthly savings;

$L_{\text {min }}-$ minimum distance in short-term period.

\section{Abbreviations:}

ANOVA - analysis of variance;

CAN - controller area network;

CPU - central processing unit;

FC - fuel consumption;

GPRS - general packet radio service;

GPS - global positioning system;

Scania FMS - Scania fleet management system;

SDS - Scania driver support;

VCI - vehicle connection interface.

\section{Introduction}

FC is the biggest component in the total energy consumption in the road transport consumption structure.

Minimizing FC has many advantages for the driver including a reduction in the financial cost and the environmental impact.

The basic classification of these factors is outlined in the literature. Odhams et al. (2010) grouped the factors that affect the FC of the heavy goods vehicles into three categories: external factors (traffic congestion, driver behaviour and weather conditions), vehicle design factors and logistical factors.

Weather conditions are classified as external factors that include a direct or indirect effect of meteorological phenomena on FC. The following three categories have the biggest impact on FC: environment temperature, air pressure and wind. Baker (1994) determined that the FC could be higher by $15 \ldots 20 \%$ in the winter compared to the

*Corresponding author. E-mail: pitka@uns.ac.rs 
summer in the Europe's conditions. Weather conditions mainly affect $\mathrm{FC}$ through the use of additional systems in the vehicle (A/C, heating system, water pumps). Due to various outdoor temperatures the heating system is used which increases the FC from 0.15 to $0.25 \mathrm{~L} / 100 \mathrm{~km}$ (Feuerecker et al. 2005).

Ambient temperature can have an effect on all types of exterior resistance to the progress of a vehicle. Lower ambient temperature leads to a higher air density and greater aerodynamic drag (Fontaras, Dilara 2012), which would, when driving on a highway, increase the FC by around $1.3 \%$ because of a greater drag (NRCAN 2014). Goodyear Tire (2008) determined that the tyre rolling resistance could also increase with the speed acceleration but with less intensity, and Michelin (2003) determined that the air temperature affected the rolling resistance tyre properties. According to research TRB (2006) higher air temperature causes lower rolling resistance. The studies confirmed that lowering of rolling resistance lead to FC savings of 1...3.5\% (Burgess, Choi 2003; ECMT 2005; Smokers et al. 2006; Continental 2015; IEA 2005).

It was established that the ambient temperature had a big influence on the cold start of the vehicle and even higher FC during a warm up phase. Other systems that also lead to an increase of FC while operating differently in the starting conditions and during the warm up phase are: engine lubrication system with its components (Hawley et al. 2010), vehicle transmission and exhaust emission system (Mock et al. 2012). If the temperature is less than $20{ }^{\circ} \mathrm{C}$ when starting the vehicle it can lead to an increase in FC by 6\% (Barrand, Bokar 2008; Mock et al. 2012). Cold start has a bigger impact on the FC at shorter distances rather than at medium and longer distances (Dardiotis et al. 2013; DOE-EPA 2019).

Moreover, Degraeuwe and Beusen (2013) studied an impact of ambient temperature on the FC and the results of their research showed an increase in FC by $0.38 \pm 0.079 \%$ when the temperature was down by $1{ }^{\circ} \mathrm{C}$. They determined that the decline of eco-driving training effects in the first six months after the course was being compensated by the increase of temperature in the spring and summer. Thereby, the effect of training is inconstant over a longer period and gradually recedes in the months after the training.

The weather conditions such as rain and snow also affect the operation of engines, ancillary systems, resistance, and even the FC because of the manner the vehicle is operated. An analysis was conducted in America about the effects of rain on the FC of heavy transport vehicles. It was determined that there was higher FC when the road was wet (Cummins 2012). Rain and snow change the characteristics of the road surface and affect the vehicle rolling resistance. The basis of this resistance is a phenomenon called "aquaplaning". Maintaining the same speed on the wet road could increase the FC by over 30\% (Karlsson et al. 2012). In addition, DOE-EPA (2019) showed that the snow and ice had an impact on increase in FC because of the reduced traction and driving slower than normal.

Many researchers supported the fact that the eco-driving training of drivers and influence on driving behaviour could be the most efficient intervention for the improvement of FC economy (Af Wåhlberg 2006, 2007; Ericsson 2001; Evans 1979; Luther, Baas 2011; Scott et al. 2012; Symmons, Rose 2009; Zarkadoula et al. 2007).

Eco-driving is a way of driving styles in a manner that minimizes FC and emissions, and also reduces vehicle maintenance costs. Eco-driving leads to a significant improvement in driving parameters, such as: smooth driving, acceleration and deceleration mode (Symmons, Rose 2009), idling time (Rutty et al. 2013), number of braking events, driving with vehicle warning, number of gear changes (Savković et al. 2016). The primary advantage of eco-driving approach is that it can be applicable to any vehicle regardless of its age and size, and it can immediately have the effect among the entire fleet vehicles.

The results presented in the literature show a high degree of variability in the reduction of FC after eco-driving training. There are a number of peer-reviewed studies investigating short-term impacts of eco-driving on FC. Basarić et al. (2017) found that driver education resulted in approximately $11.71 \%$ reduction in FC immediately after the training, but (Husnjak et al. 2015) recorded a reduction of FC from as much as $23 \%$. Driver and Vehicle Standards Agency (UK) showed improving of fuel efficiency by $8.5 \%$ after two-hour training (UKERC 2006). A study carried out in Sweden indicates the average savings of $10.9 \%$ in FC after the training (Shaheen et al. 2012). Ford Motor Company (US) claims that there is a $24 \%$ improvement in fuel economy shortly after the training (Green Car Congress 2008). Sullman et al. (2015) showed that fuel economy improved by $11.6 \%$ immediately after the training.

A few studies have presented the long-term effects of eco-driving on FC. Af Wåhlberg (2007) monitored reduction in FC in buses and noted 2\% fuel savings over the course of one-year after driver training. A yearlong study from 2002 held in the Netherlands, with 6000 car drivers divided into eco drivers and non-eco drivers, showed a $7 \%$ fuel savings per kilometre by eco-drivers (SenterNovem 2005). Beusen et al. (2009) found that average FC decreased by $5.85 \%$ four months after the initial eco-driving training.

Eco-driving training was found to be effective in the reduction of FC in the short run although a longer-term analysis indicates that the impact is reduced over time. Barla et al. (2017) measured the impact of eco-driving training session for the period of up to ten months and they showed that reductions of FCs faded progressively after the training. Namely, fuel efficiency in the city is reduced by about half within ten months. Both studies - Af Wåhlberg (2007) and Zarkadoula et al. (2007) implied that the effect of eco-driving training might be decreased in the long run. They reported that eco-driving can save $10 \ldots 15 \%$ during training, but this decreases to 
about $4 \ldots 5 \%$ three months after training and long-term savings are about $2 \%$. Wu et al. (2015) showed that the benefit of eco-driving in fuel economy for three taxi drivers increased on average by $19.04 \%$ in the short-term (immediately after eco-driving training) but decreased to $14.41 \%$ four months after taking eco-driving training. These findings indicate that drivers partially return to a less economic driving behaviour, subsequently leading to the lower fuel savings after a while. Dogan et al. (2011) claim that eco-driving, as a modern and efficient way of driving, is difficult to turn into a driving habit because it is depend on driving situations.

The key to mitigate climate change in the shortest time is to incorporate eco-driving as part of the driving style of drivers on the roads to reduce carbon emissions alongside with fuel savings. A few researches have shown positive effects of eco-driving on the environment and significant reduction in $\mathrm{CO}_{2}$ emissions. Husnjak et al. (2015) showed that after applying eco-driving style, $\mathrm{CO}_{2}$ emissions were reduced by $31 \%$ compared to the normal driving. Barth and Boriboonsomsin (2009) found it is possible to reduce $\mathrm{CO}_{2}$ emissions approximately $10 \ldots 20 \%$ by using ecodriving. Barkenbus (2010) indicated that eco-driving can reduce $\mathrm{CO}_{2}$ emissions from driving by $10 \%$. Rolim et al. (2014) also showed the reduction in $\mathrm{CO}_{2}$ emissions after the eco-driving education.

Because of all the above, apart from the affirmatively justifiable investments in the fleet vehicles in order to reduce a total cost of transport companies (Stojić et al. 2018), one should invest in eco-driving training. However, the ambient temperature has a direct impact on traffic safety. At lower temperatures, which correlate with precipitation, wet and slippery road, reduced visibility (rainfall and fog), etc., there are variations and speed limits. All these phenomena degrade the traffic flow until the occurrence of traffic congestion. Detailed analysis of all these phenomena based on a large number of studies was presented by Theofilatos and Yannis (2014). Cited phenomena, primarily due to a reduction in average travelling speed and variations in speed (forced decelerations and frequent accelerations), increase the FC. Under lower temperature conditions, risky situations are more frequent. The drivers are familiar with that fact, which significantly changes their perception ( $\mathrm{Li}$ et al. 2018). The drivers adjust the psychomotor driving concept to estimation and the prevention of avoiding the risky situations.

The eco-driving conditions require drivers' specific psychomotor involvement. This involvement must not impair the safety. It is a common knowledge that eco-driving may have a negative impact on safety under different circumstances, for example, where the safety limits are in conflict with the aim of maintaining the constant speed (Young et al. 2011). All meteorological phenomena that occur in the lower average ambient temperatures are not in favour of the basic eco-driving concept. Therefore, it is safe to assume that the eco-driving conditions at lower average ambient temperatures are limited with making safe driving a priority. As a result, the primary benefits of eco-driving: $\mathrm{FC}$ economy and reduction of $\mathrm{CO}_{2}$ emission, cannot be substantiated.

The present study examines the impacts of eco-driving training course (through theoretical and practical training initiatives) are evaluated by monitoring FC and SDS parameter during the one-year observation period. This one-year period covered the average ambient temperature cycle of a wider geographical region. Thereby, the conditions for research of possible direct and indirect impacts of average ambient temperature on eco-driving effects were established.

\section{Worldwide eco-driving activities}

Eco-driving training was confirmed to be effective in the reduction of $\mathrm{FC}$ and $\mathrm{CO}_{2}$ emission in the short-term although a longer-term analysis indicated that the impact was reduced over time. Very important issue is raised as to how to sustain improved driving behaviour over a long period of time. The research on long-term effects of ecodriving is scarce (Af Wåhlberg 2002a), although it has been proven that teaching a different driving style can often reduce consumption by tens of percent during the training (Greene 2008; Af Wåhlberg 2002b), and the economic and environmental potential is therefore great. An aptitude for a positive change is considerable, if the following is to be involved: a well-founded campaign, state-of-the-art education, use of feedback devices, fiscal incentives and norm reinforcement (Beusen et al. 2009; Barkenbus 2010). Accordingly, Mcllroy and Stanton (2015) claimed there is necessity for both government and industry involvement with the prior understanding of how the people comprehend eco-driving, and what they already know of it.

A good practice in European Union shows that regulations already require eco-driving to be taught to novice drivers. As part of their national strategies for the reduction of $\mathrm{CO}_{2}$ emissions, several European countries as well as Japan also included the eco-driving programs (ITF 2007). Barkenbus (2010) highlights that in the US, eco-driving as a style that changes driving behaviour, becomes the norm. The US Government has defined ecodriving programs and measures to achieve major savings, to overcome low public expectations of success. This can be accomplished through implementation interstate speed limit and influencing public awareness through information campaigns and highlighting the cost savings that can be achieved. In addition, government monetary assistance to individuals for the purchase feedback devices in their vehicles can have a positive impact on savings. Another measure of the US Government contributing to this is allowing eco-driving programs free and available to drivers whose costs will be paid by the automobile industry and the government.

Researchers believe the use of eco-driving feedback devices can significantly affect driving behaviour unlike driver education. Harvey et al. (2013) claim the introduc- 
tion of eco-driving feedback devices into new cars may be very useful for changing driver behaviour. Honda (Japan) installed Eco Assist ${ }^{\text {(x) }}$ dashboard in its Insight vehicle so the drivers could have an estimate on how to successfully reach the maximum FC performance (The Spec 2009). The drivers can check the records on fuel economy instantly as well as over the duration of an entire trip. Nissan (Japan) vehicles are equipped with colour-coded horizontal bar for FC measurement that changes its length and colour depending on driver's behaviour (Woodyard 2007).

McIlroy and Stanton (2015) suggest that eco-driving information system should be applied to novice ecodriver and should support the behaviours themselves that characterise fuel-efficient driving. Based on the literature review, the authors have identified different activities (deceleration to lower speed, deceleration for road curvature, deceleration full stop, acceleration, headway maintenance) that have the most significant effects on fuel economy of the road vehicles. These activities were modelled and the models were considered as support to drivers, particularly those currently lacking in eco-driving expertise.

However, when transporting hazardous materials, where the driving conditions are predefined and the biggest emphasis is placed on selection of the route with the lowest risk size (Ebrahimi, Tadic 2018) and maximum speed limit, the use of eco-driving tips in the urban areas is limited.

\section{Methodology}

\subsection{Participants}

Eco-driving training and education of drivers in transport companies that are using Scania FMS on the territory of the former Yugoslavian Republics (Bosnia and Herzegovina. Montenegro, Croatia, Republic of North Macedonia, Slovenia and Serbia) is being conducted in the laboratory of the company Scania in Ljubljana (Slovenia). The size of the group was limited by the capacity of the laboratory (8 posts). Eco-driving training course is evaluated by monitoring parameters: FC, $\mathrm{CO}_{2}$ emissions and SDS parameter of a group of 7 drivers who voluntarily agreed to be monitored during the one-year longitudinal study whereby are showing the daily operating parameters records through monthly average. They were all professional truck drivers who have not had any previous experience with eco-driving.

\subsection{Test vehicle}

For eco-drive test, testing and measuring of the defined indicators were performed on the combination of truck Scania R410 LA4X2MNA ${ }^{(m)}$ and semitrailer Schmitz ${ }^{(i \times}$.

\subsection{Test route}

The chosen route has a length of $50 \mathrm{~km}$ and contains various network categories (urban, rural and highway) to ensure more realistic conditions and to illustrate better advantages of the use of Scania FMS (Table 1). Every driver travelled the same route twice in order to avoid deviations in FCs due to different travelling distances: first while driving normally (before eco-driving training) and second after eco-driving training with an instructor.

\subsection{Scania FMS}

Scania FMS ${ }^{(m)}$ is the factory service devised to provide a follow-up of the driver and vehicle performances. In order to use the Scania FMS services, it is necessary to have a Scania Communicator C200 ${ }^{\circledR}$ telematics unit (Figure 1) installed in the vehicle, which transfers data between the vehicle and the office without driver interaction (Figure 2). This unit consists of several circuits that are connected to the CPU, which keeps the system running and handles all data exchange within the platform. To keep track of the vehicle, a GPS receiver provides the C200 with vehi-

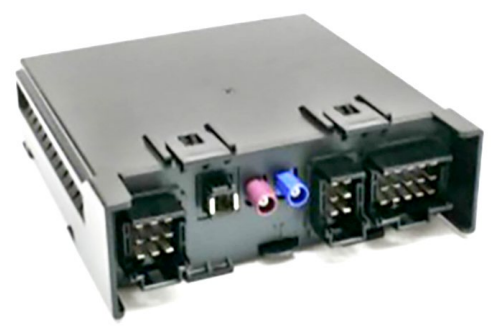

Figure 1. Scania Communicator C200

Table 1. Testing route

\begin{tabular}{|l|c|l|l|}
\hline \multicolumn{1}{|c|}{ Testing route } & Distance $[\mathrm{km}]$ & \multicolumn{1}{|c|}{ Characteristics } & \multicolumn{1}{c|}{ Comment } \\
\hline $\begin{array}{l}\text { Śmarjeta - Novo Mesto } \\
\text { (road number 448) }\end{array}$ & 12 & $\begin{array}{l}\text { regional road; } \\
\text { passing through settlements roundabouts }\end{array}$ & $\begin{array}{l}\text { the driver has a better possibility to get } \\
\text { acquainted with anticipation and timely } \\
\text { braking }\end{array}$ \\
\hline $\begin{array}{l}\text { Novo Mesto - Trebnje } \\
\text { (highway A2) }\end{array}$ & 13 & $\begin{array}{l}\text { highway; } \\
\text { entrance to the roundabouts and exit of } \\
\text { the roundabouts }\end{array}$ & $\begin{array}{l}\text { the driver has a possibility to evaluate the } \\
\text { right following distance and select the } \\
\text { highway speed }\end{array}$ \\
\hline $\begin{array}{l}\text { Trebnje - Novo Mesto } \\
\text { (highway A2) }\end{array}$ & 13 & $\begin{array}{l}\text { highway; } \\
\text { entrance to the roundabouts and exit of } \\
\text { the roundabouts }\end{array}$ & the same route in return \\
\hline $\begin{array}{l}\text { Novo Mesto - Šmarjeta } \\
\text { (road number 448) }\end{array}$ & 12 & $\begin{array}{l}\text { regional road; } \\
\text { passing through settlements roundabouts }\end{array}$ & the same route in return \\
\hline
\end{tabular}




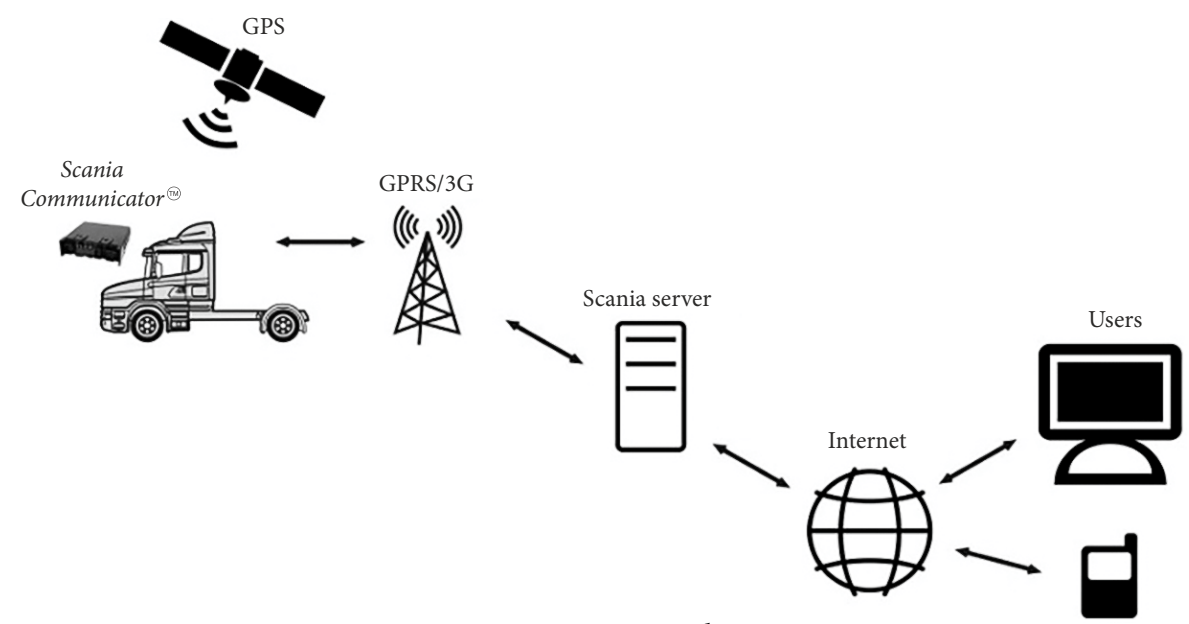

Figure 2. Scania FMS architecture

cle position and speed. Data readings and writings from the local CAN bus is done through a CAN interface that supplies the platform with information about the vehicle speed and other parameters available on the bus. The actual telecommunication unit is a GPRS modem that handles all data traffic between the vehicle and the office.

The software is refreshed periodically and the latest version is updated in the vehicle with the diagnostic software SDP3 (Scania Diagnos \& Programmer). This software works only with Scania VCIs (VCI 2 and VCI 3 - diagnostic interfaces for connection with vehicles) and is compatible with the latest Scania trucks and engines.

\subsubsection{SDS}

Scania Driver Support ${ }^{(1)}$ as part of Scania FMS provides real-time hints and feedback to the drivers during driving and aims to assist the drivers in developing a driving style that reduces FC, emission and wear on the vehicle. This method of driver behaviour evaluation is a support for the driver in maintaining the skills developed through training over a longer period of time.

SDS is based on the skills acquired during driver training and includes four assessment categories (Figure 3):

- hill driving: evaluates how the accelerator pedal and vehicle's momentum are utilised in varying topography;

- anticipation: heavy accelerations and decelerations, as well as the interval between accelerating and braking, are used to assess how well the driver anticipates different situations;

- brake use: evaluates the frequency and harshness of brake applications;

- choice of gears: matches gear selection and engine revolutions to save fuel.

SDS continually analyses data from various sensors on the vehicle to monitor driver performance. The system assesses driving and the driver's average score is displayed in percentage for each category. They are also added together in an average score (Figure 4) as shown graphically. The average score is calculated for all driving results that are
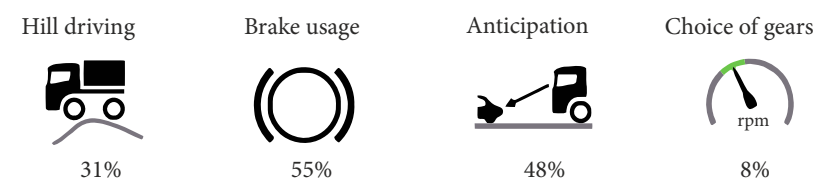

Figure 3. Average driving results display according to the SDS

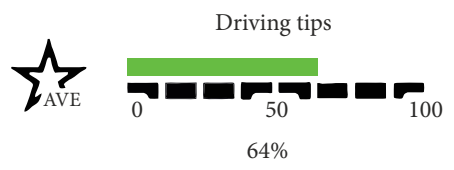

Figure 4. Average score

recorded in all categories, even if one category is activated only briefly.

The higher SDS value shows greater possibility for lower vehicle amortization and lower vehicle maintenance costs (less brake system wear, less engine wear, etc.) and lower transport company operating costs.

\subsection{The data evaluation}

For data evaluation, it was used the post-hoc Duncan's multiple range test for ANOVA of SDS parameter, $\mathrm{CO}_{2}$ emission and FC by factors: Time (months) and distance $(\mathrm{km} \cdot 1000)$. Nevertheless, to determine the dependence between $\mathrm{FC}$ and $\mathrm{CO}_{2}$ emission during the observation period, it was used a linear correlation.

The analysis was carried out using statistical program Microsoft Statistica version 12.

\subsection{Training}

Eco-driving training and education of 7 drivers were conducted in the period from May through June 2015 in Ljubljana (Slovenia). All drivers attended two-day training sessions over the same two-month period. The eco-driving training consisted of 3 phases:

- phase I: the first test drive was done on a predefined route with drivers driving in their unique style prior to application of eco-driving advices and guidelines. This serves as a control point of comparison with the 
subsequent second test drive to assess the potential of fuel savings, reduction of $\mathrm{CO}_{2}$ emission and SDS increasing made via eco-driving training. After this test drive, the measurements were collected by Scania FMS;

- phase II: after phase I, a two-hour theoretical ecodriving training was carried out. The results of the first test drive were presented to the drivers and they were given information and advices on how and where the savings could be achieved and what they meant for the drivers, the company owner and the vehicle. Advices were related to: number of braking events reduction, the proper distance between vehicles, shifting up gears early, use of vehicle inertia, idling time reduction, harsh deceleration and acceleration reduction, checking tire pressures before driving, etc.;

- phase III: upon completing theoretical education phase, the drivers conducted the second test drive on the same route the first test drive was carried out. Basically, the second test drive denotes the modified driving style with the incorporation of eco-driving tips.

During this test drive, the instructor was in the vehicle and he was actively involved in the driver's decision-making. When the drivers did not implement the knowledge acquired during theoretical training, the instructor was giving suggestions and advices,

When comparing the first and second test drive, the changes were detected after the implementation of fuel-efficient driving suggestions. No further instructions or feedback was provided to participants after the training day.

After phase III, the findings were discussed with the drivers and they were given instructions for further improvement. The results of the entire observation period are presented in Figure 5 and Table 2.

\section{Results and discussion}

The driving results for 7 drivers were analysed in the short period and the long period after the training, compared to the period before the training, using 3 parameters: (1) FC, (2) $\mathrm{CO}_{2}$ emission, (3) SDS parameter. The results indicated that the benefits of eco-driving are most prominent immediately after the training. As time after completion of the training passes, its benefits decrease.

Separation of monitoring period to short-term and long-term impacts of eco-driving is adopted on the basis of the established FC economy results regardless of the average monthly values of ambient temperatures, and will be further illustrated.

The study had the following time arrangements (Table 2):

- pre-course period: 1-30 April 2015;

- short-term impacts of eco-driving with eco-driving training: 1 May - 30 June 2015;

- short-term impacts of eco-driving without eco-driving training: 1 July - 30 October 2015;

- long-term impacts of eco-driving: 1 November 2015 - 30 April 2016.
Table 3 shows the average SDS parameter values per months and the results of the post-hoc Duncan's test for ANOVA. The average SDS parameter value was $S D S(0)=65.57 \%$ before training and this value is adopted as a reference for the statistical analysis of SDS values. It is obvious that the drivers enter a training process with a low average value of SDS parameter, however, the parameter value increases during training, reaching its maximum in the second month after the training with the average $S D S(4)=77.14 \%$ value, and the third month after the training with the average $S D S(5)=76.71 \%$ value. These two average values significantly differ in comparison to the average SDS value before the training, $p(4)=0.0384$ and $p(5)=0.0453$ respectively. Significant increase in SDS values points to the fact that the training made a significant progress in the way driving is approached during those two months. In the long-term, the SDS parameter values are constant and permanently higher than the initial values. However, whilst the SDS values in the longterm are higher than the initial and the values achieved during training, they are not significantly different according to the variance analysis.

Obtained result favours utilization of eco-driving with the $p=0.05$. This certainly raises a question about the consistency of the effects of training, which achieves the best effects after the training during the months of July and August. However, if the $p=0.10$ is adopted, the significant effects are already achieved during training in June, reaching its maximum after the training during the months of July and August, and then losing its effect during the period from October through December, only to appear again during the period from January through March. Sensibility of driving characteristics, acceleration, braking and speed excesses, known as "driving errors" with eco-driving training, was established by DíazRamirez et al. (2017). These driving errors are identical to categories evaluated by SDS parameter. The researchers ascertained that the reduction of driving errors up to $96 \%$ was feasible with the implementation of eco-driving training, which would then achieve the FC savings.

Table 4 shows comparison of average monthly FC values per time factor. It is performed using the post-hoc Duncan's test for ANOVA. ANOVA points in August with a minimum of $F C(4)=25.64 \mathrm{~L} / 100 \mathrm{~km}$, whereas the extreme maximum values are achieved in November and December with the average consumption of $F C(4)=25.64 \mathrm{~L} / 100 \mathrm{~km}$ and $F C(8)=28.62 \mathrm{~L} / 100 \mathrm{~km}$, respectively. It is evident that the FC minimum does not have any significant differences with the previous monthly periods (May, June and July) and consecutive monthly periods (September and October) but it does have with the months during winter. We determined that in the fifth month after the training (month 7), the drivers return to their old driving habits with the same FC as in the period before the training. Obtained results point out to the possible impact of meteorological factors, and primarily, the impact of ambient temperature on the average FC. 
Table 2. Sum of research data before and after eco-driving training

\begin{tabular}{|c|c|c|c|c|c|c|c|c|c|c|c|c|c|c|c|}
\hline \multirow{3}{*}{ Driver } & \multirow{3}{*}{ Parameter } & 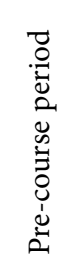 & \multicolumn{2}{|c|}{ 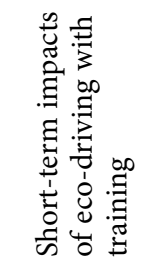 } & \multicolumn{4}{|c|}{$\begin{array}{l}\text { Short-term impacts } \\
\text { of eco-driving without } \\
\text { training }\end{array}$} & \multicolumn{6}{|c|}{$\begin{array}{l}\text { Long-term impacts } \\
\text { of eco-driving }\end{array}$} & 范 \\
\hline & & 0 & 1 & 2 & 3 & 4 & 5 & 6 & 7 & 8 & 9 & 10 & 11 & 12 & $7 \ldots 12$ \\
\hline & & $\begin{array}{l}\frac{20}{2} \\
\stackrel{i}{7} \\
\frac{0}{2}\end{array}$ & 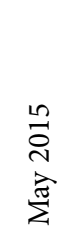 & 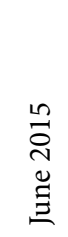 & 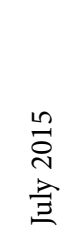 & 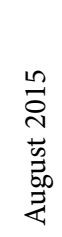 & 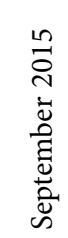 & 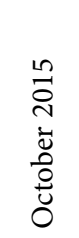 & 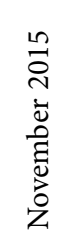 & 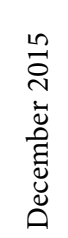 & 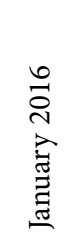 & 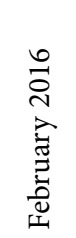 & 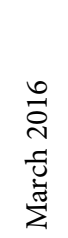 & 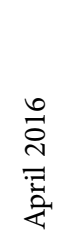 & 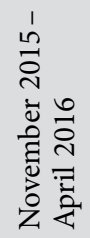 \\
\hline \multirow{4}{*}{1} & SDS $^{1}$ & 62 & 64 & 65 & 63 & 63 & 65 & 64 & 65 & 64 & 64 & 64 & 63 & 63 & 63.83 \\
\hline & $\mathrm{FC}^{2}$ & 28 & 26.2 & 27.5 & 26 & 25.6 & 28.4 & 27 & 29.4 & 27.7 & 29.2 & 30.9 & 28.4 & 29 & 29.10 \\
\hline & $\mathrm{CO}_{2}$ emission $^{3}$ & 0.76 & 0.70 & 0.74 & 0.70 & 0.69 & 0.76 & 0.73 & 0.79 & 0.74 & 0.79 & 0.83 & 0.76 & 0.78 & 0.78 \\
\hline & Distance $^{4}$ & 11.9 & 10.5 & 11.9 & 12.3 & 10.7 & 12.3 & 12.9 & 13.0 & 8.9 & 10.3 & 11.1 & 10.1 & 9.9 & 10.55 \\
\hline \multirow{4}{*}{2} & SDS & 60 & 79 & 94 & 88 & 86 & 85 & 84 & 84 & 79 & 76 & 77 & 79 & 78 & 78.83 \\
\hline & FC & 28.6 & 27.2 & 24.9 & 26.4 & 25.1 & 25.1 & 27.8 & 26.1 & 29.3 & 27.5 & 27.6 & 28.7 & 29.2 & 28.07 \\
\hline & $\mathrm{CO}_{2}$ emission & 0.77 & 0.73 & 0.67 & 0.71 & 0.67 & 0.67 & 0.75 & 0.70 & 0.78 & 0.75 & 0.74 & 0.76 & 0.78 & 0.75 \\
\hline & Distance & 13.5 & 8.1 & 12.4 & 11.5 & 10.1 & 12.3 & 12.2 & 12.8 & 9.3 & 11.4 & 9.8 & 8.5 & 9.6 & 10.23 \\
\hline \multirow{4}{*}{3} & SDS & 77 & 80 & 81 & 79 & 87 & 86 & 85 & 85 & 74 & 77 & 78 & 77 & 81 & 78.67 \\
\hline & FC & 28 & 28.4 & 26.2 & 27.7 & 25 & 26.7 & 27.2 & 29.9 & 30.5 & 28.5 & 29 & 28.1 & 30.1 & 29.35 \\
\hline & $\mathrm{CO}_{2}$ emission & 0.77 & 0.73 & 0.67 & 0.71 & 0.67 & 0.67 & 0.75 & 0.70 & 0.78 & 0.75 & 0.74 & 0.76 & 0.78 & 0.75 \\
\hline & Distance & 12.9 & 9.9 & 12.5 & 10.9 & 8.9 & 13.9 & 14.3 & 12.1 & 8.2 & 10.9 & 9.8 & 10.6 & 10.1 & 10.28 \\
\hline \multirow{4}{*}{4} & SDS & 68 & 73 & 88 & 90 & 82 & 83 & 64 & 61 & 62 & 84 & 84 & 87 & 83 & 76.83 \\
\hline & FC & 27.5 & 26.6 & 26.8 & 26.5 & 28.2 & 27.9 & 28.2 & 29.2 & 29.4 & 27.1 & 27.6 & 28.4 & 28.1 & 28.30 \\
\hline & $\mathrm{CO}_{2}$ emission & 0.74 & 0.71 & 0.72 & 0.72 & 0.75 & 0.75 & 0.76 & 0.79 & 0.79 & 0.73 & 0.75 & 0.76 & 0.75 & 0.76 \\
\hline & Distance & 13.5 & 10.1 & 13.5 & 13.0 & 6.5 & 13.9 & 13.3 & 10.9 & 10.9 & 10.6 & 8.0 & 8.4 & 11.8 & 10.1 \\
\hline \multirow{4}{*}{5} & SDS & 66 & 64 & 65 & 67 & 79 & 81 & 78 & 77 & 79 & 77 & 76 & 79 & 74 & 77.00 \\
\hline & FC & 26.6 & 26.4 & 27.7 & 27.1 & 25.7 & 26.7 & 25.8 & 30.8 & 29.9 & 28 & 26.4 & 30.8 & 28.7 & 29.10 \\
\hline & $\mathrm{CO}_{2}$ emission & 0.71 & 0.71 & 0.75 & 0.73 & 0.69 & 0.72 & 0.70 & 0.83 & 0.80 & 0.75 & 0.71 & 0.83 & 0.77 & 0.78 \\
\hline & Distance & 12.6 & 12.0 & 12.7 & 7.5 & 11.7 & 11.3 & 12.2 & 12.5 & 8.6 & 9.1 & 11.0 & 11.5 & 8.8 & 10.25 \\
\hline \multirow{4}{*}{6} & SDS & 67 & 66 & 68 & 76 & 77 & 74 & 73 & 73 & 73 & 74 & 74 & 73 & 73 & 73.33 \\
\hline & FC & 25.8 & 24.1 & 25.1 & 23.5 & 23.9 & 24.8 & 25.3 & 25.9 & 26.5 & 25.2 & 26.1 & 23.4 & 24.8 & 25.32 \\
\hline & $\mathrm{CO}_{2}$ emission & 0.70 & 0.65 & 0.68 & 0.63 & 0.64 & 0.67 & 0.68 & 0.70 & 0.71 & 0.67 & 0.69 & 0.63 & 0.67 & 0.68 \\
\hline & Distance & 13.5 & 11.3 & 11.7 & 12.5 & 5.9 & 12.7 & 11.5 & 11.2 & 10.5 & 10.4 & 9.5 & 9.9 & 10.9 & 10.40 \\
\hline \multirow{4}{*}{7} & SDS & 59 & 61 & 67 & 66 & 66 & 63 & 65 & 67 & 68 & 69 & 71 & 66 & 68 & 68.17 \\
\hline & FC & 29.3 & 28.5 & 24.7 & 25.3 & 26 & 26.5 & 24.1 & 27.2 & 27.1 & 26.7 & 27.8 & 24.5 & 26.2 & 26.58 \\
\hline & $\mathrm{CO}_{2}$ emission & 0.79 & 0.77 & 0.67 & 0.68 & 0.70 & 0.72 & 0.65 & 0.73 & 0.73 & 0.72 & 0.74 & 0.66 & 0.70 & 0.71 \\
\hline & Distance & 12.0 & 10.4 & 11.7 & 13.1 & 8.9 & 12.3 & 12.0 & 10.7 & 11.8 & 9.6 & 8.2 & 9.4 & 11.5 & 10.20 \\
\hline \multirow{5}{*}{ 范 } & SDS & 66 & 70 & 75 & 76 & 77 & 77 & 73 & 73 & 71 & 74 & 75 & 75 & 74 & 73.67 \\
\hline & $\mathrm{FC}$ & 27.7 & 26.7 & 26.2 & 26.0 & 25.6 & 26.6 & 26.5 & 28.4 & 28.5 & 27.5 & 28.0 & 27.5 & 27.9 & 27.97 \\
\hline & $\mathrm{CO}_{2}$ emission & 0.74 & 0.72 & 0.71 & 0.70 & 0.69 & 0.72 & 0.71 & 0.76 & 0.77 & 0.74 & 0.75 & 0.73 & 0.75 & 0.75 \\
\hline & Distance & 12.9 & 10.3 & 12.3 & 11.5 & 9.0 & 12.7 & 12.6 & 11.9 & 9.7 & 10.3 & 9.6 & 9.8 & 10.4 & 10.28 \\
\hline & $\begin{array}{l}\text { Monthly } \\
\text { temperature }\end{array}$ & 10 & 15 & 18 & 20 & 19 & 16 & 10 & 3 & 1 & 0 & 3 & 5 & 10 & 3.67 \\
\hline
\end{tabular}

Notes: ${ }^{1}$ driver's average score [\%]; ${ }^{2}$ average FC $[\mathrm{L} / 100 \mathrm{~km}] ;{ }^{3}$ average $\mathrm{CO}_{2}$ emission $[\mathrm{kg} / \mathrm{km}] ;{ }^{4}$ average distance $\left[\mathrm{km} \cdot 10^{3}\right] ;{ }^{5}$ average monthly temperature $\left[{ }^{\circ} \mathrm{C}\right]$ (ARSO 2018). 
Table 3. $p$-values from post-hoc Duncan's test for ANOVA for all average monthly values of the SDS parameter during the observed period

\begin{tabular}{|c|c|c|c|c|c|c|c|c|c|c|c|c|c|}
\hline \multirow[b]{3}{*}{$\begin{array}{c}\text { Time } \\
\text { [month] }\end{array}$} & \multirow{2}{*}{$\begin{array}{c}\text { Pre-training } \\
0 \\
\end{array}$} & \multicolumn{2}{|c|}{$\begin{array}{l}\text { Short-term impacts } \\
\text { of eco-driving with } \\
\text { training }\end{array}$} & \multicolumn{4}{|c|}{$\begin{array}{l}\text { Short-term impacts of eco-driving } \\
\text { without training }\end{array}$} & \multicolumn{6}{|c|}{ Long-term impacts of eco-driving } \\
\hline & & 1 & 2 & 3 & 4 & 5 & 6 & 7 & 8 & 9 & 10 & 11 & 12 \\
\hline & 芯 & 玩 & 当 & 齐 & 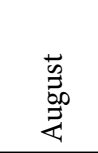 & $\begin{array}{l}\bar{\bigsqcup} \\
\text { हँँ } \\
\text { ڤँच }\end{array}$ & $\begin{array}{l}\vec{\Xi} \\
\stackrel{0}{0} \\
\stackrel{U}{0}\end{array}$ & 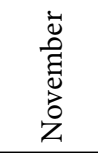 & 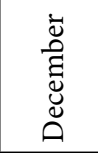 & 栉 & 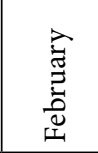 & 荡 & $\overline{\bar{Z}}$ \\
\hline SDS [\%] & 65.57 & 69.57 & 75.42 & 75.57 & 77.14 & 76.71 & 73.28 & 73.14 & 71.28 & 74.42 & 74.85 & 74.85 & 74.28 \\
\hline$p$-value & - & 0.3859 & 0.0741 & 0.0718 & 0.0384 & 0.0453 & 0.1392 & 0.1367 & 0.2451 & 0.0994 & 0.0904 & 0.0873 & 0.1001 \\
\hline
\end{tabular}

Table 4. $p$-values from post-hoc Duncan's test for ANOVA for all average monthly values of the FC during the observed period

\begin{tabular}{|c|c|c|c|c|c|c|c|c|c|c|c|c|c|}
\hline \multirow[b]{3}{*}{$\begin{array}{c}\text { Time } \\
{[\text { month] }}\end{array}$} & \multirow{2}{*}{$\begin{array}{c}\text { Pre-training } \\
0\end{array}$} & \multicolumn{2}{|c|}{$\begin{array}{c}\text { Short-term impacts } \\
\text { of eco-driving with } \\
\text { training }\end{array}$} & \multicolumn{4}{|c|}{$\begin{array}{c}\text { Short-term impacts of eco-driving } \\
\text { without training }\end{array}$} & \multicolumn{6}{|c|}{ Long-term impacts of eco-driving } \\
\hline & & 1 & 2 & 3 & 4 & 5 & 6 & 7 & 8 & 9 & 10 & 11 & 12 \\
\hline & 逽 & 产 & $\stackrel{\Xi}{\Xi}$ & $\underline{\Xi}$ & 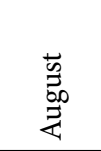 & 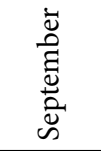 & $\begin{array}{l}\dot{\Xi} \\
\stackrel{0}{0} \\
\stackrel{U}{0}\end{array}$ & $\begin{array}{l}\dot{\bar{\nu}} \\
\ddot{\Xi} \\
\overline{0} \\
0 \\
z\end{array}$ & 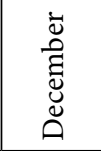 & 氞 & 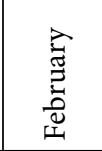 & $\begin{array}{l}\tilde{0} \\
\stackrel{0}{\pi}\end{array}$ & 节 \\
\hline $\begin{array}{l}\mathrm{FC} \\
{[\mathrm{L} / 100 \mathrm{~km}]}\end{array}$ & 27.68 & 26.77 & 26.12 & 26.07 & 25.64 & 26.58 & 26.48 & 28.35 & 28.62 & 27.45 & 27.91 & 27.47 & 28.01 \\
\hline 0 & & 0.3379 & 0.1211 & 0.1119 & 0.0446 & 0.2605 & 0.2279 & 0.4824 & 0.3356 & 0.8039 & 0.7902 & 0.8030 & 0.7209 \\
\hline 1 & 0.3379 & & 0.5013 & 0.4756 & 0.2572 & 0.8289 & 0.7562 & 0.1143 & 0.0662 & 0.4255 & 0.2422 & 0.4460 & 0.2115 \\
\hline 2 & 0.1211 & 0.5013 & & 0.9470 & 0.5972 & 0.6190 & 0.6777 & 0.0291 & 0.0145 & 0.1729 & 0.0778 & 0.1764 & 0.0646 \\
\hline 3 & 0.1119 & 0.4756 & 0.9470 & & 0.6180 & 0.5909 & 0.6523 & 0.0261 & 0.0128 & 0.1627 & 0.0711 & 0.1645 & 0.0587 \\
\hline 4 & 0.0446 & 0.2572 & 0.5972 & 0.6180 & & 0.3356 & 0.3773 & 0.0080 & 0.0035 & 0.0697 & 0.0260 & 0.0707 & 0.0207 \\
\hline 5 & 0.2605 & 0.8289 & 0.6190 & 0.5909 & 0.3356 & & 0.9074 & 0.0803 & 0.0446 & 0.3425 & 0.1811 & 0.3533 & 0.1559 \\
\hline 6 & 0.2279 & 0.7562 & 0.6777 & 0.6523 & 0.3773 & 0.9074 & & 0.0667 & 0.0363 & 0.3083 & 0.1559 & 0.3139 & 0.1328 \\
\hline 7 & 0.4824 & 0.1143 & 0.0291 & 0.0261 & 0.0080 & 0.0803 & 0.0667 & & 0.7521 & 0.3674 & 0.6300 & 0.3660 & 0.6899 \\
\hline 8 & 0.3356 & 0.0662 & 0.0145 & 0.0128 & 0.0035 & 0.0446 & 0.0363 & 0.7521 & & 0.2462 & 0.4547 & 0.2452 & 0.5038 \\
\hline 9 & 0.8039 & 0.4255 & 0.1729 & 0.1627 & 0.0697 & 0.3425 & 0.3083 & 0.3674 & 0.2462 & & 0.6329 & 0.9868 & 0.5706 \\
\hline 10 & 0.7902 & 0.2422 & 0.0778 & 0.0711 & 0.0260 & 0.1811 & 0.1559 & 0.6300 & 0.4547 & 0.6329 & & 0.6300 & 0.9074 \\
\hline 11 & 0.8030 & 0.4460 & 0.1764 & 0.1645 & 0.0707 & 0.3533 & 0.3139 & 0.3660 & 0.2452 & 0.9868 & 0.6300 & & 0.5704 \\
\hline 12 & 0.7209 & 0.2115 & 0.0646 & 0.0587 & 0.0207 & 0.1559 & 0.1328 & 0.6899 & 0.5038 & 0.5706 & \begin{tabular}{|l|}
0.9074 \\
\end{tabular} & 0.5704 & \\
\hline
\end{tabular}

FC and $\mathrm{CO}_{2}$ emission correlate. Consequent similarity can be found in the linear correlation $\left(\mathrm{CO}_{2}=\right.$ $0.00346+0.02676 \cdot F C)$ with the high correlation coefficient $r=0.99822$. Value with variable FC is 0.02676 , which is consistent with the standard value of $\mathrm{CO}_{2}$ emissions/L of fuel (density of $0.85 \mathrm{~g} / \mathrm{cm}^{3}$ ) of $\approx 2.7 \mathrm{~kg}$. Because of confirmed high functional linear dependency between FC and $\mathrm{CO}_{2}$ emission, it is adequate to choose just one out of these two functional variables from the analysis about the impact of Eco-driving effects. Average FC was selected for the reference variable.

Figure 5 shows a two-dimensional dependency of variable FC functioning as independent variables: time and distance. It is obvious in the graphic that the position of minimum does not change with the distance covered and that the values of the average FC are invariant from distance. This way, the possible impact of distance on average
FC, is ruled out. Because of assumption about the possible impact of ambient temperature on FC, approach to this analysis is discussed further in the paper.

Figure 6 shows synchronously indicated values of FC and average ambient temperature in comparison to the time period of eco-driving study. A visually distinctive inverse ratio between these two functions can be seen in the graphic. High values of average ambient temperature are found in the FC minimums, and the values of the lowest ambient temperatures are found at the highest values of the average FC. This system of values emphasizes the strong impact of ambient temperature on the average FC and thereby, indirectly, on the effects of training drivers on eco-driving.

However, in Table 3, the ANOVA of SDS parameter value with $p$-value ( $p=0.10)$ verifies a significant impact of training, that is absent during the period from October 


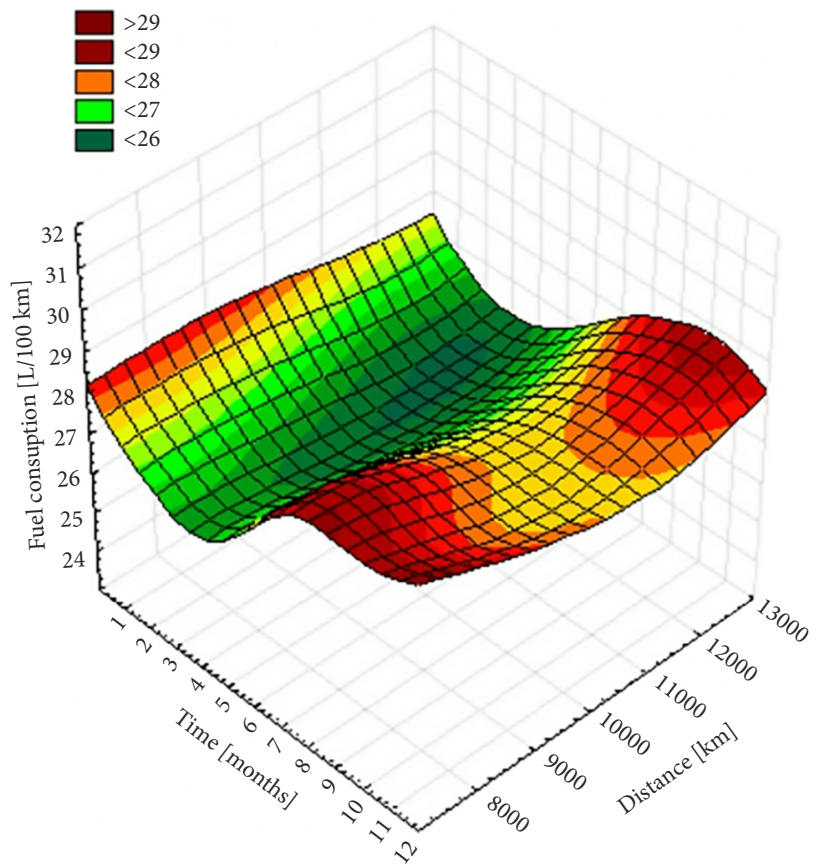

Figure 5. FCs a function of distance and the time (3D space)

through December, only to appear again in January, February and March. It should be noted here that the impact of training on SDS is emphasized in the month of minimum ambient average temperature (January). This directs us at the synergic impact of eco-driving and average ambient temperature.

A functional relation between the time, as independently variable, and FC, as dependently variable, is determined with a 4-degree equation and the correlation $r=0.8806\left(R^{2}=0.7755\right)$. The first derivative of a function (Equation (1)) has a minimum in value $x=2.66254$ months.

$$
\begin{aligned}
& f^{\prime}(x)=\left(0.001 \cdot x^{4}-0.050 \cdot x^{3}+\right. \\
& \left.0.541 \cdot x^{2}-1.893 \cdot x+27.9\right)^{\prime}=0 .
\end{aligned}
$$

Figure 7 illustrates applied quadratic function of average ambient temperature and average FC. Applied quadratic function $f_{c}(T)=-0.005 \cdot T^{2}-0.016 \cdot T+28.04$ $[\mathrm{L} / 100 \mathrm{~km}]$ is rated with the high correlation coefficient $R^{2}=0.767$. This function has the synergic impact of ecodriving effect and the impact of average ambient temperature. Obtained results are in accordance with the previous research Degraeuwe and Beusen (2013), which originally established the impact of average ambient temperature on FC in driving conditions.

On the basis of this function (Figure 7), an estimate on theoretical values of the average FC with absolute impact of temperature without presumed impact of eco-driving can be made. Values of the theoretical FC $f_{c t}$ are obtained directly from the quadric function with the conversion of average ambient temperatures. By forming this dependent variable, we get a comparative basis for testing of average FC. Empirical values of FC $f_{c e}$ are existing established values of average FC (Table 2). Average values of empirical and theoretical FC are calculated for short-term and longterm period. Results are shown in Table 5.

By utilizing post-hoc Duncan's test for ANOVA of empirical and theoretical average values of FC in the shortterm and long-term period, the following results were obtained:

- between the average values of empirical FC (26.277 \pm $0.412 \mathrm{~L} / 100 \mathrm{~km})$ and theoretical FC $(26.747 \pm 0.434$ $\mathrm{L} / 100 \mathrm{~km}$ ) in the short-term period, a significant difference was established, $p=0.0310$. In the empirical conditions of eco-driving, the average FC was significantly lower regardless of the impact of temperature; - between the average values of empirical FC (27.968 \pm $0.467 \mathrm{~L} / 100 \mathrm{~km})$ and theoretical FC $(27.904 \pm 0.1531$ $\mathrm{L} / 100 \mathrm{~km}$ ) in the long-term period, no significant difference was established, $p=0.7554$. There was no difference in the average FC in the long-term period, regardless of the impact of temperature.

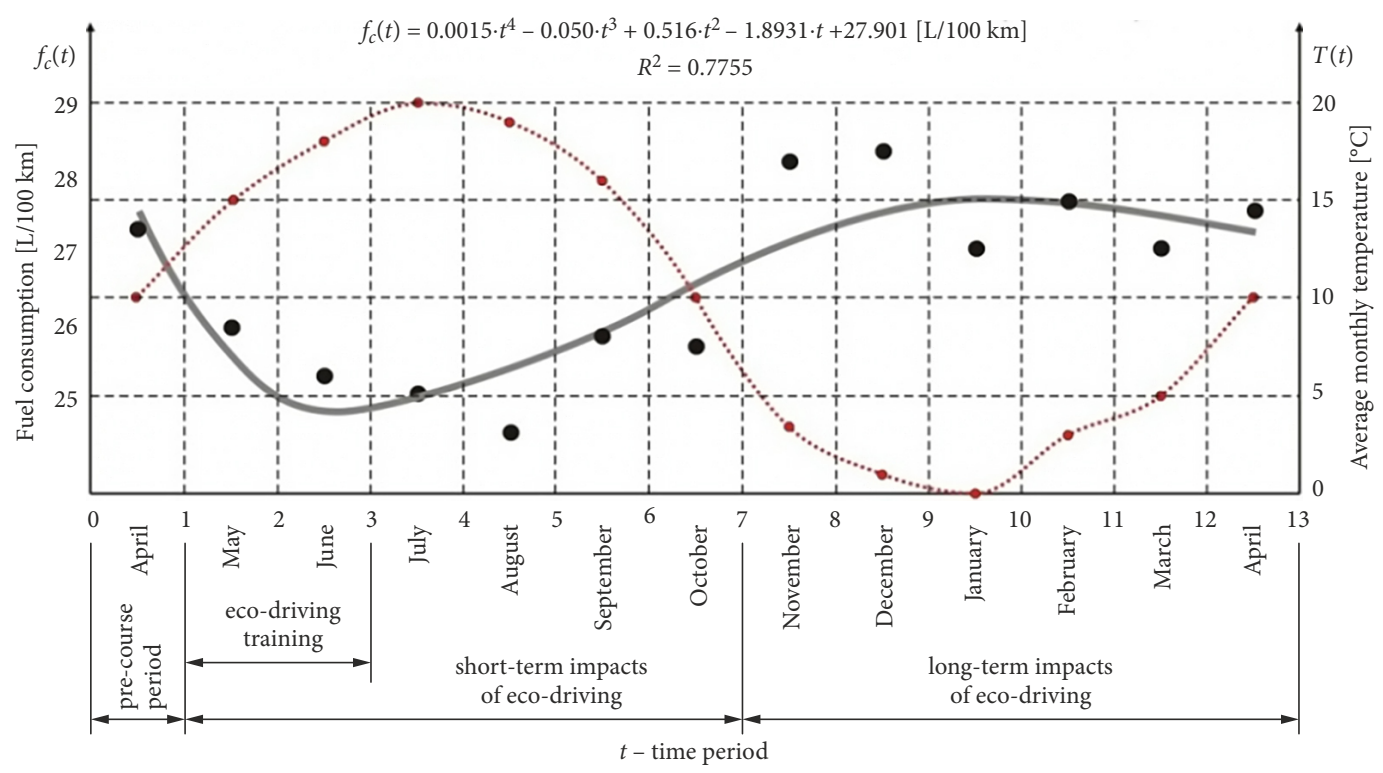

Figure 6. Distribution of FC (correlation function) and average monthly temperature 


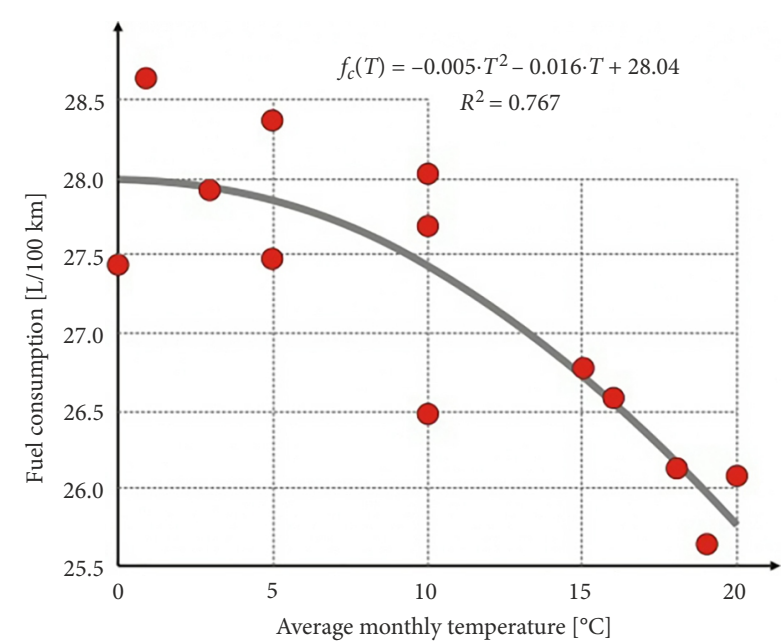

Figure 7. FC as a function of average monthly temperature

This is also the base for declaration of long-term and short-term eco-driving periods. If we take into account that, between the average value of empirical FC in the longterm period $(27.97 \mathrm{~L} / 100 \mathrm{~km})$ and initial consumption value before the training in April $2015(27.70 \mathrm{~L} / 100 \mathrm{~km})$, no significant difference is established, $p=0.2606>0.05$, a conclusion can be drawn that the impact of driver training is completely lost in the long-term period.

\subsection{Economic benefits}

Assessment of the fuel savings allows calculation of the economic advantages for a transport company. With the characteristic parameters, for each driver who completed the eco-driving training course, can be calculated the month savings. In order to save in $\mathrm{FC}$ a difference between the empirical and theoretical values in the short-term period can be adopted, and it is $\Delta=26.747-26.277=$ $0.47 \mathrm{~L} / 100 \mathrm{~km}$.

With differential equation in FC of $0.47 \mathrm{~L} / 100 \mathrm{~km}$ and with an average covered distance of $11003 \mathrm{~km}$ for all drivers, an average monthly FC saving of $57.7141 \mathrm{~L}$ (Equation (2)) could be achieved, i.e. $46.543 \mathrm{EUR} / \mathrm{veh}$ for the price of $1 \mathrm{~L}$ of fuel $0.9 \mathrm{EUR}$. At the same time, $\mathrm{CO}_{2}$ emission would be reduced to around $139.628 \mathrm{~kg}$ on average during a month (Equation (3)), that would amount to around $19.548 \mathrm{EUR} / \mathrm{veh}$ considering the price of $\mathrm{CO}_{2}$ rehabilitation of $140 \mathrm{EUR} / \mathrm{t}$ (Tanackov et al. 2011). In that respect, total monthly savings for $\mathrm{FC}$ and $\mathrm{CO}_{2}$ emission would amount to $66.091 \mathrm{EUR} / \mathrm{veh}$. For short-term period, in this case 6 months, and the cost of driver training in the amount of $250 \mathrm{EUR}$, the training participation in the monthly period is 250/6 (Equation (4)), which corresponds to the savings for the average distance of $11003 \mathrm{~km}$. In this case, the following monthly savings per vehicle are made.

$\Delta_{F C(\text { vehicle })}=\frac{(26.747-26.277)}{100} \cdot 11.003=51.7141[\mathrm{~L} / \mathrm{veh}] ;$

$\Delta_{\mathrm{CO}_{2}(\text { vehicle })} \cong 51.7141 \cdot 2.7=139.628[\mathrm{~kg} / \mathrm{veh}] ;$

$\Delta_{E B(\text { vehicle })}=66.091-\frac{250}{6}=24.394[\mathrm{EUR} / \mathrm{veh}]$.

Generally, all savings are reduced to mileage. In the short-term period, with the impact of eco-driving, the following results for $\mathrm{FC}$ economy (Equation (5)), $\mathrm{CO}_{2}$ emission (Equation (6)) and economic benefits are obtained (Equation (7)).

$$
\begin{aligned}
& \Delta_{F C(\mathrm{~km})}=\frac{26.747-26.277}{100}=0.0047[\mathrm{~L} / \mathrm{km}] \\
& \Delta_{\mathrm{CO}_{2}(\mathrm{~km})} \cong 0.0047 \cdot 2.7=0.01269[\mathrm{~kg} / \mathrm{km}] \\
& \Delta_{E B(\mathrm{~km})}=0.0047 \cdot 0.90+0.01269 \cdot 0.378= \\
& 0.00903[\mathrm{EUR} / \mathrm{km}] .
\end{aligned}
$$

Based on economic benefits data (Equation (7)), the minimum obtained mileage $L_{\min }$ a driver has to complete in the short-term period in order to justify the training investment of 250 EUR (Equation (8)):

$$
L_{\min }=\frac{250}{0.00903}=27685.49[\mathrm{~km}] \text {. }
$$

\begin{tabular}{|c|c|c|c|c|c|c|c|c|c|c|c|c|}
\hline & 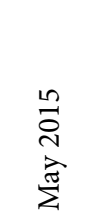 & $\begin{array}{l}\text { no } \\
\stackrel{0}{N} \\
0 \\
\Xi \\
\Xi\end{array}$ & $\begin{array}{l}\frac{n}{0} \\
\stackrel{2}{N} \\
\underline{E}\end{array}$ & 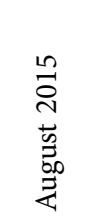 & 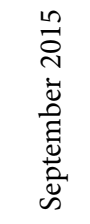 & 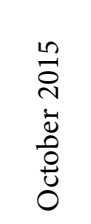 & 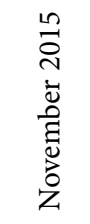 & 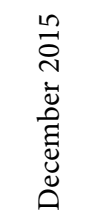 & 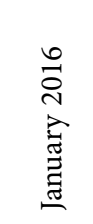 & 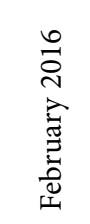 & 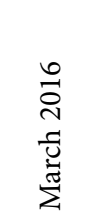 & $\begin{array}{l}\underset{0}{0} \\
\stackrel{\sim}{\sim} \\
\stackrel{\vec{Z}}{0}\end{array}$ \\
\hline Period & \multicolumn{6}{|c|}{ Short-term impacts of eco-driving } & \multicolumn{6}{|c|}{ Long-term impacts of eco-driving } \\
\hline Average temperature $\left[{ }^{\circ} \mathrm{C}\right]$ & 15 & 18 & 20 & 19 & 16 & 10 & 3 & 1 & 0 & 3 & 5 & 10 \\
\hline$f_{c e}[\mathrm{~L} / 100 \mathrm{~km}]$ & 26.77 & 26.12 & 26.07 & 25.64 & 26.58 & 26.48 & 28.35 & 28.62 & 27.45 & 27.91 & 27.47 & 28.01 \\
\hline Average of $f_{c e}$ & \multicolumn{6}{|c|}{$26.277 \pm 0.412$} & \multicolumn{6}{|c|}{$27.968 \pm 0.467$} \\
\hline$f_{c t}[\mathrm{~L} / 100 \mathrm{~km}]$ & 27.10 & 26.70 & 26.40 & 26.56 & 26.97 & 27.60 & 27.96 & 27.99 & 28.00 & 27.96 & 27.90 & 27.60 \\
\hline Average of $f_{c t}$ & \multicolumn{6}{|c|}{$26.747 \pm 0.434$} & \multicolumn{6}{|c|}{$27.904 \pm 0.1531$} \\
\hline
\end{tabular}

The utilization of $L_{\min }$ in the case of a short-term period of 6 months and $11003 \mathrm{~km}$ completed by each driver or $66018 \mathrm{~km}$ in the short-term period indicated that $41.94 \%$

Table 5. Empirical and theoretical values of average FC in the overall observation period with average ambient temperature 
of covered distance was needed to justify the investment in the training. If we accept that the significant impact of training is 6 month period, the minimum average monthly mileage that secures profitability of investment in driver training is $4614.28 \mathrm{~km}$ or $153.81 \mathrm{~km} /$ day.

Obtained results, above all, recognize the impact of environmental temperature, which includes synthetic impact of bad driving conditions on FC. Calculated savings with eco-driving are exact but approximately five times lower, on average, than in the previous studies.

Zarkadoula et al. (2007) have calculated that the annual savings based on the characteristic parameters for each bus would be 1697 EUR amounting to 2884900 EUR over the 1700 bus fleet. Barić et al. (2013) have shown that the annual savings, after training of one commercial vehicle, would be 1505 EUR amounting to $2257500 \mathrm{EUR} /$ year over the 1500 vehicles in the fleet.

\section{Conclusions}

The paper focused on th 'e influence of driver training and ambient temperature on FC and SDS parameter.

The obtained research results confirm a positive effect of eco-driving concept, but also a high sensitivity of these effects on the ambient conditions of driving. Effects of eco-driving are not permanent and are significantly degraded by the bad weather driving conditions. In addition, it is established that the effects of eco-driving do not depend on the covered distance but on the elapsed period from the start of training. Economic and ecological effects are positive and justify the investment in drivers' training. This rationalizes the proposition about the periodical ecodriving conditioning of drivers.

As per obtained results, the assumptions can be made that even in good environmental conditions there are factors, which suppress the effects of eco-driving. For example, during traffic congestion, heavy cargo vehicles adjust speed variations with difficulty. Furthermore, variable characteristics of the route (bends, uphill, downhill) can dictate the driving conditions, which do not meet the basic principles of eco-driving. Therefore, it is safe to assume that the introduction of the trained drivers with the geometrical characteristics of the route in advance contributes to the optimal use of eco-driving tips. A conclusion can be drawn that the external driving conditions are principal for achieving the positive eco-driving effects. In this paper, it was only established for the ambient temperature. For further research on impact of temperature on eco-driving effects, the next research plan is recommended. It should be conducted over a minimum one-year period with three groups of drivers without previous eco-driving experience. These groups should have previously established significantly same initial SDS parameter values. First group are drivers who will not attend eco-driving training. Second group are drivers who will attend the eco-driving training only at the beginning of the observation period. Third group are drivers who will attend the eco-driving training at the beginning and then sporadically during the obser- vation period. SDS parameter values should be recorded for all three groups of drivers during the entire research period. Regular recording of average ambient temperature will establish the comparative basis for precise substantiating of eco-driving effects.

\section{References}

Af Wåhlberg, A. E. 2002a. Att mäta effekter av utbildning i sparsam körning. Uppsala universitet, Sverige. $10 \mathrm{~s}$. (in Swedish).

Af Wåhlberg, A. E. 2002b. Fuel efficient driving training - state of the art and quantification of effects, in Proceedings of the 2nd Safety on Road International Conference SORIC'2002, 21-23 October 2002, Bahrain, Paper E141, 1-6.

Af Wåhlberg, A. E. 2007. Long-term effects of training in economical driving: fuel consumption, accidents, driver acceleration behavior and technical feedback, International Journal of Industrial Ergonomics 37(4): 333-343.

https://doi.org/10.1016/j.ergon.2006.12.003

Af Wåhlberg, A. E. 2006. Short-term effects of training in economical driving: passenger comfort and driver acceleration behavior, International Journal of Industrial Ergonomics 36(2): 151-163. https://doi.org/10.1016/j.ergon.2005.10.001

ARSO. 2018. Mesečni bilten ARSO. Agencija Republike Slovenije za okolje (ARSO). Available from Internet: http://www.arso. gov.si/o\%20agenciji/knji\%C5\%BEnica/mese\%C4\%8Dni\%20 bilten (in Slovenian).

Baker, M. 1994. Fuel Consumption and Emission Models for Evaluating Traffic Control and Route Guidance Strategies. MSc Thesis. Queen's University, Kingston, ON, Canada. 302 p.

Barić, D.; Zovak, G.; Periša, M. 2013. Effects of eco-drive education on the reduction of fuel consumption and $\mathrm{CO}_{2}$ emissions, PROMET - Traffic \& Transportation 25(3): 265-272. https://doi.org/10.7307/ptt.v25i3.1260

Barkenbus, J. N. 2010. Eco-driving: An overlooked climate change initiative, Energy Policy 38(2): 762-769. https://doi.org/10.1016/j.enpol.2009.10.021

Barla, P.; Gilbert-Gonthier, M.; López Castro, M. A.; MirandaMoreno, L. 2017. Eco-driving training and fuel consumption: impact, heterogeneity and sustainability, Energy Economics 62: 187-194. https://doi.org/10.1016/j.eneco.2016.12.018

Barrand, J.; Bokar, J. 2008. Reducing tire rolling resistance to save fuel and lower emissions, SAE International Journal of Passenger Cars - Mechanical Systems 1(1): 9-17. https://doi.org/10.4271/2008-01-0154

Barth, M.; Boriboonsomsin, K. 2009. Energy and emissions impacts of a freeway-based dynamic eco-driving system, Transportation Research Part D: Transport and Environment 14(6): 400-410. https://doi.org/10.1016/j.trd.2009.01.004

Basarić, V. B.; Jambrović, M.; Miličić, M. B.; Savković, T. M.; Basarić, Đ. M.; Bogdanović, V. Z. 2017. Positive effects of ecodriving in public transport: a case study of the city Novi Sad, Thermal Science 21(1): 683-692.

https://doi.org/10.2298/TSCI150219160B

Beusen, B.; Broekx, S.; Denys, T.; Beckx, C.; Degraeuwe, B.; Gijsbers, M.; Scheepers, K.; Govaerts, L.; Torfs, R.; Panis, L. I. 2009. Using on-board logging devices to study the longerterm impact of an eco-driving course, Transportation Research Part D: Transport and Environment 14(7): 514-520. https://doi.org/10.1016/j.trd.2009.05.009

Burgess, S. C.; Choi, J. M. J. 2003. A parametric study of the energy demands of car transportation: a case study of two competing commuter routes in the UK, Transportation Research Part D: Transport and Environment 8(1): 21-36. https://doi.org/10.1016/S1361-9209(02)00016-0 
Continental. 2015. EU Tyre Label. Continental AG, Hanover, Germany. Available from Internet: https://www.continentaltyres.co.za/truck/knowhow/eu-tire-label-truck

Cummins. 2012. Secrets of Better Fuel Economy: the Physics of MPG. Cummins MPG Guide. Cummins Inc., Columbus, IN, US. 35 p. Available from Internet: https://www.idleair.com/ wp-content/uploads/2011/02/2012-04-26-Cummins-Secretsof-Fuel-Economy-Idling-pgs-29-and-32.pdf

Dardiotis, C.; Martini, G.; Marotta, A.; Manfredi, U. 2013. Lowtemperature cold-start gaseous emissions of late technology passenger cars, Applied Energy 111: 468-478.

https://doi.org/10.1016/j.apenergy.2013.04.093

Degraeuwe, B.; Beusen, B. 2013. Corrigendum on the paper "Using on-board data logging devices to study the longer-term impact of an eco-driving course", Transportation Research Part D: Transport and Environment 19: 48-49.

https://doi.org/10.1016/j.trd.2012.11.003

Díaz-Ramirez, J.; Giraldo-Peralta, N.; Flórez-Ceron, D.; Rangel, V.; Mejía-Argueta, C.; Huertas, J. I.; Bernal, M. 2017. Eco-driving key factors that influence fuel consumption in heavy-truck fleets: a Colombian case, Transportation Research Part D: Transport and Environment 56: 258-270.

https://doi.org/10.1016/j.trd.2017.08.012

DOE-EPA. 2019. Fuel Economy in Cold Weather. US Department of Energy (DOE) - US Environmental Protection Agency (EPA). Available from Internet:

https://www.fueleconomy.gov/feg/coldweather.shtml

Dogan, E.; Steg, L.; Delhomme, P. 2011. The influence of multiple goals on driving behavior: the case of safety, time saving, and fuel saving, Accident Analysis \& Prevention 43(5): 1635-1643. https://doi.org/10.1016/j.aap.2011.03.002

Ebrahimi, H.; Tadic, M. 2018. Optimization of dangerous goods transport in urban zone, Decision Making: Applications in Management and Engineering 1(2): 131-152.

ECMT. 2005. Making Cars More Fuel Efficient: Technology for Real Improvements on the Road. European Conference of Ministers of Transport (ECMT). 83 p. Available from Internet: https://www.itf-oecd.org/sites/default/files/docs/05cars.pdf

Ericsson, E. 2001. Independent driving pattern factors and their influence on fuel-use and exhaust emission factors, Transportation Research Part D: Transport and Environment 6(5): 325-345. https://doi.org/10.1016/S1361-9209(01)00003-7

Evans, L. 1979. Driver behavior effects on fuel consumption in urban driving, Human Factors: The Journal of the Human Factors and Ergonomics Society 21(4): 389-398. https://doi.org/10.1177/001872087902100401

Feuerecker, G.; Schäfer, B.; Strauss, T. 2005. Auxiliary heating systems of conventional and heat pump type: technology, performance and efficiency, SAE Technical Paper 2005-01-2055. https://doi.org/10.4271/2005-01-2055

Fontaras, G.; Dilara, P. 2012. The evolution of European passenger car characteristics 2000-2010 and its effects on real-world $\mathrm{CO}_{2}$ emissions and $\mathrm{CO}_{2}$ reduction policy, Energy Policy 49: 719-730. https://doi.org/10.1016/j.enpol.2012.07.021

Greene, D. L. 2008. Near Term Options to Increase Fuel Economy and Decrease Petroleum Demand. Testimony to the US Senate Committee on Energy and Natural Resources. Energy and Natural Resources Committee Office, Washington, DC, US. 8 p. Available from Internet: https://www.energy.senate.gov/public/index.cfm/files/serve?File_id=50b54f8d-d264-f3b8-a73340be4e51ddb5

Goodyear Tire. 2008. Factors Affecting Truck fuel Economy. Goodyear Commercial Tire Systems. The Goodyear Tire \& Rubber Company. 4 p. Available from Internet: https://www. goodyeartrucktires.com/pdf/resources/publications/factors_ affecting_truck_fuel_economy.pdf

Green Car Congress. 2008. Ford Testing Shows Eco-Driving Improved Fuel Economy an Average 24\%. Green Car Congress: Energy, Technologies, Issues and Policies for Sustainable Mobility. Available from Internet: https://www.greencarcongress. com/2008/08/ford-testing-sh.html

Harvey, J.; Thorpe, N.; Fairchild, R. 2013. Attitudes towards and perceptions of eco-driving and the role of feedback systems, Ergonomics 56(3): 507-521.

https://doi.org/10.1080/00140139.2012.751460

Hawley, J. G.; Bannister, C. D.; Brace, C. J.; Akehurst, S.; Pegg, I.; Avery, M. R. 2010. The effect of engine and transmission oil viscometrics on vehicle fuel consumption, Proceedings of the Institution of Mechanical Engineers, Part D: Journal of Automobile Engineering 224(9): 1213-1228.

https://doi.org/10.1243/09544070JAUTO1534

Husnjak, S.; Forenbacher, I.; Bucak, T. 2015. Evaluation of ecodriving using smart mobile devices, PROMET - Traffic \& Transportation 27(4): 335-344. https://doi.org/10.7307/ptt.v27i4.1712

IEA. 2005. Saving Oil in a Hurry. International Energy Agency (IEA). 168 p. Available from Internet: https://www.iea.org/reports/saving-oil-in-a-hurry-2005

ITF. 2007. Findings and messages for policy makers, in Workshop on Ecodriving, 22-23 November 2007, International Transport Forum (ITF), Paris, France. 6 p. Available from Internet: https://thepep.unece.org/node/506

Karlsson, R.; Carlson, A.; Dolk, E. 2012. Energy Use Generated by Traffic and Pavement Maintenance: Decision Support for Optimization of Low Rolling Resistance Maintenance Treatments. VTI Report 36A-2012. Swedish National Road and Transport Research Institute (VTI). Linköping, Sweden. 47 p. Available from Internet: https://www.vti.se/en/publications/ publication/energy-use-generated-by-traffic-and-pavementmaint_669289

Li, Y.; Zheng, Y.; Wang, J.; Kodaka, K.; Li, K. 2018. Crash probability estimation via quantifying driver hazard perception, Accident Analysis \& Prevention 116: 116-125.

https://doi.org/10.1016/j.aap.2017.05.009

Luther, R.; Baas, P. 2011. Eco-driving Scoping Study. New Zealand: AA Research Foundation, The New Zealand Automobile Association Inc. 83 p. Available from Internet: https:// www.aa.co.nz/assets/about/Research-Foundation/Ecodrive/ TERNZ-Eco-Driving-Report.pdf

McIlroy, R. C.; Stanton, N. A. 2015. A decision ladder analysis of eco-driving: the first step towards fuel-efficient driving behaviour, Ergonomics 58(6): 866-882.

https://doi.org/10.1080/00140139.2014.997807

Michelin. 2003. The Tyre: Rolling Resistance and Fuel Savings. Société de Technologie Michelin, Clermont-Ferrand, France. $120 \mathrm{p}$.

Mock, P.; German, J.; Bandivadekar, A.; Riemersma, I. 2012. Discrepancies between Type-Approval and Real-World Fuel Consumption and $\mathrm{CO}_{2}$ Values in 2001-2011 European Passenger Cars. Working paper 2012-02. International Council on Clean Transportation. 13 p. Available from Internet: https:// theicct.org/sites/default/files/publications/ICCT_EU_fuelconsumption2_workingpaper_2012.pdf

NRCAN. 2014. Learn the Facts: Cold Weather Effects on Fuel Efficiency. Natural Resources Canada (NRCAN), Government of Canada. 2 p. Available from Internet: https://www.nrcan. gc.ca/sites/www.nrcan.gc.ca/files/oee/pdf/transportation/ fuel-efficient-technologies/autosmart_factsheet_3_e.pdf 
Odhams, A. M. C.; Roebuck, R. L.; Lee, Y. J.; Hunt, S. W.; Cebon, D. 2010. Factors influencing the energy consumption of road freight transport, Proceedings of the Institution of Mechanical Engineers, Part C: Journal of Mechanical Engineering Science 224(9): 1995-2010. https://doi.org/10.1243/09544062JMES2004

Rolim, C. C.; Baptista, P. C.; Duarte, G. O.; Farias, T. L. 2014. Impacts of on-board devices and training on light duty vehicle driving behavior, Procedia - Social and Behavioral Sciences 111: 711-720. https://doi.org/10.1016/j.sbspro.2014.01.105

Rutty, M.; Matthews, L.; Andrey, J.; Del Matto, T. 2013. Eco-driver training within the city of Calgary's municipal fleet: monitoring the impact, Transportation Research Part D: Transport and Environment 24: 44-51.

https://doi.org/10.1016/j.trd.2013.05.006

Savković, T.; Miličić, M.; Atanasković, P.; Pitka, P.; Milenković, I. 2016. Impact of eco-driving on the environment and transport company operations, Suvremeni Promet - Modern Traffic 36(5-6): 283-285.

Scott, H.; Knowles, M.; Morris, A.; Kok, D. 2012. The role of a driving simulator in driver training to improve fuel economy, in Driving Simulation Conference 2012, 6-7 September 2012, Paris, France, 1-7.

SenterNovem. 2005. Ecodriving: The Smart Driving Style. SenterNovem - Agency of the Ministry of Economic Affairs, The Netherlands. 31 p.

Shaheen, S. A.; Martin, E. W.; Finson, R. S. 2012. Ecodriving and Carbon Footprinting: Understanding How Public Education Can Reduce Greenhouse Gas Emissions and Fuel Use. MTI Report 11-11. Mineta Transportation Institute (MTI), San Jose, CA, US. 184 p. Available from Internet: https://transweb.sjsu. edu/research/ecodriving-and-carbon-footprinting-understanding-how-public-education-can-reduce-greenhouse

Smokers, R.; Vermeulen, R.; Van Mieghem, R.; Gense, R.; Skinner, I.; Fergusson, M.; MacKay, E.; Ten Brink, P.; Fontaras, G.; Samaras, Z. 2006. Review and Analysis of the Reduction Potential and Costs of Technological and other Measures to Reduce $\mathrm{CO}_{2}$-Emissions from Passenger Cars. Final Report. Contract No SI2.408212. European Commission. 303 p.

Stojić, G.; Sremac, S.; Vasiljković, I. 2018. A fuzzy model for determining the justifiability of investing in a road freight vehicle fleet, Operational Research in Engineering Sciences: Theory and Applications 1(1): 62-75.

Sullman, M. J. M.; Dorn, L.; Niemi, P. 2015. Eco-driving training of professional bus drivers - does it work?, Transportation Research Part C: Emerging Technologies 58: 749-759. https://doi.org/10.1016/j.trc.2015.04.010

Symmons, M. A.; Rose, G. 2009. Ecodrive training delivers substantial fuel savings for heavy vehicle drivers, in Driving Assessment 2009: 5th International Driving Symposium on Human Factors in Driving Assessment, Training and Vehicle Design, 22-25 June 2009, Big Sky, MT, US, 46-53.

Tanackov, I.; Tepić, J.; Stojić, G.; Sremac, S.; Simić, D. 2011. Balance of the $\mathrm{CO}_{2}$ emission on the corridor X through Serbia and proposals for remediation of the part of the emission applying transportation-logistics systems, in Proceedings of the 24th International Conference on Efficiency, Cost, Optimization, Simulation and Environmental Impact of Energy Systems, ECOS 2011, 4-7 July 2011, Novi Sad, Serbia, 3: 2268-2276.

The Spec. 2009. Honda's Eco Assist System. The Hamilton Spectator (The Spec). Available from Internet: https://www.thespec. com/autos-story/2086536-honda-s-eco-assist-system
Theofilatos, A.; Yannis, G. 2014. A review of the effect of traffic and weather characteristics on road safety, Accident Analysis \& Prevention 72: 244-256.

https://doi.org/10.1016/j.aap.2014.06.017

TRB. 2006. Tires and Passenger Vehicle Fuel Economy: Informing Consumers, Improving Performance. Special Report 286. Transportation Research Board (TRB), Washington, DC, US. 178 p. Available from Internet: http://www.trb.org/Publications/Blurbs/157125.aspx

UKERC. 2006. Quick Hit: Eco-Driving. UK Energy Research Centre (UKERC). Available from Internet: http://www.ukerc. ac.uk/publications/quick-hit-eco-driving.html

Woodyard, C. 2007. Nissan to Put Lead-Foot Gauge on All Models. ABC News. Available from Internet: https://abcnews.go.com/Business/story?id=3508421

Wu, Y.; Zhao, X.; Rong, J. 2015. The long-term effectiveness of eco-driving training: a pilot study, in Proceedings of the Eighth International Driving Symposium on Human Factors in Driver Assessment, Training and Vehicle Design, 22-25 June 2015, Salt Lake City, Utah, US, 212-218.

https://doi.org/10.17077/drivingassessment.1574

Young, M. S.; Birrell, S. A.; Stanton, N. A. 2011. Safe driving in a green world: a review of driver performance benchmarks and technologies to support 'smart' driving, Applied Ergonomics 42(4): 533-539. https://doi.org/10.1016/j.apergo.2010.08.012

Zarkadoula, M.; Zoidis, G.; Tritopoulou, E. 2007. Training urban bus drivers to promote smart driving: a note on a Greek eco-driving pilot program, Transportation Research Part D: Transport and Environment 12(6): 449-451. https://doi.org/10.1016/j.trd.2007.05.002 